\title{
Hubungan Keterampilan Komunikasi Interpersonal dan Konseling oleh Mahasiswa Kebidanan dengan Kepuasan Klien di Bidan Praktik Mandiri
}

\author{
Neli Sunarni, ${ }^{1}$ Tina D. Judistiani, ${ }^{2}$ Zahrotur R. Hinduan, ${ }^{3}$ Hadyana Sukandar, ${ }^{4}$ Tita H. Madjid, ${ }^{5}$ \\ Indun L. Setyono ${ }^{6}$ \\ ${ }^{1}$ Mahasiswa Program Studi Magister Kebidanan Fakultas Kedokteran Universitas Padjadjaran \\ ${ }^{2,4}$ Departemen Epidemiologi dan Biostatistik Fakultas Kedokteran Universitas Padjadjaran \\ ${ }^{3}$ Departemen Psikologi Industri dan Organisasi Fakultas Psikologi Universitas Padjadjaran \\ ${ }^{5}$ Departemen Obstetri dan Ginekologi Fakultas Kedokteran Universitas Padjadjaran \\ ${ }^{6}$ Departemen Psikologi Pendidikan Fakultas Psikologi Universitas Padjadjaran
}

\begin{abstract}
Abstrak
Keberhasilan komunikasi interpersonal dalam konseling seorang bidan akan diuji bila menghadapi klien sesungguhnya. Kualitas komunikasi interpersonal dan konseling oleh mahasiswa kebidanan belum pernah dievaluasi, oleh karena itu, mahasiswa pada saat melakukan praktik kebidanan dilakukan penilaian keterampilan komunikasi interpersonal dan konseling oleh pembimbing klinik. Keterampilan komunikasi interpersonal dan konseling merupakan aspek penting dalam pelayanan KB dan kesehatan reproduksi, karena konseling membantu klien mengatasi masalah yang dihadapinya dalam memilih dan memutuskan jenis kontrasepsi yang akan digunakan sesuai dengan kebutuhannya, sehingga klien merasa puas atas pilihan dan pelayanan yang diterimanya. Penelitian observasional potong lintang dilaksanakan di empat lokasi Bidan Praktik Mandiri Kabupaten Ciamis pada bulan Agustus 2015. Subjek penelitian adalah mahasiswa kebidanan tingkat III semester VI yang sudah lulus mata kuliah pelayanan Keluarga Berencana sebanyak 46 orang dengan teknik pengambilan sampel secara random sampling. Calon akseptor KB yang datang ke Bidan Praktik Mandiri dinilai apakah memenuhi kriteria inklusi dan eksklusi, selanjutnya calon akseptor KB dipilih secara konsekutif sampai tercapai 46 orang. Data diperoleh menggunakan daftar tilik dan kuesioner, dianalisis dengan uji korelasi. Hasil penelitian menunjukkan bahwa tidak terdapat hubungan antara teknik konseling, perilaku empati dalam konseling yang ditampilkan mahasiswa, perilaku yang mencerminkan etika dalam konseling dengan kepuasan klien dengan nilai $p>0,05$. Tidak terdapatnya hubungan diduga karena pada saat penilaian hanya dinilai dari kepatuhan melakukan langkah klinik, namun tidak menilai isi atau materi konseling. Menilai empati tidak dinilai oleh klien, butir penilaian empati tidak dibuat secara khusus. Masih terdapatnya bias dalam proses penilaian dan mungkin juga dalam proses seleksi. Simpulan hasil penelitian, tidak terdapat hubungan antara teknik konseling, perilaku empati dalam konseling dan perilaku etika dalam konseling dengan kepuasan klien.
\end{abstract}

Kata Kunci: Komunikasi interpersonal, teknik konseling, perilaku empati, perilaku etika, kepuasan klien.

Korespondensi :Perum Graha Persada Blok C No.55 Sindangkasih Ciamis. Hp.081220340516 Email: nelisunarni13@gmail.com 


\title{
Relationship Between Interpersonal Communication and Counseling Skill By Midwifery Students with Client Satisfaction In Independent Midwives Practice
}

\begin{abstract}
The successfull of interpersonal communication of counseling a midwife will be assessed while she serves the real client. The quality of interpersonal communication and counseling by the midwifery students has never been evaluated, by this reason, the students while doing midwifery practice have been assessed for their skills by their clinical instructor in interpersonal communication and ounseling. Interpersonal Communicationdan Counseling skills is an important aspect in family planning service and reproduction health, because this counseling helps the clients to choose and deside the kinds of contraception to used based on her needs. Therefore, she feels satisfied by her choice and service. A cross-sectional observational research is done in the four Independent Midwives Practice locations in Ciamis Regency on August 2015. The subjects of the research, by random sampling technique, are 46 students of the third grade or the sixth semester of midwifery students who also passed the family planning service subject. The candidate of family planning acceptors who come to Independent Midwives Practice are assessed whether they fulfil the inclusion and exclusion criteria, and than they are chosen consecutively until 46 candidates. The data are taken from checklists and questionnaire and analyzed by correlation test. The results shows that there is no correlation among counseling techniques, empathy behaviour performed by students in counseling, the ethical behavior reflects in counseling and the clients satisfaction by $p>0.05$. this is suspected from the assessment that is only valued from their obedience to do the clinical procedure, not from the content or the counseling material assesment. To evaluate empathy does not be assessed by the clients and emphaty assessment item are not specifically made. Therefore, there is bias in assessment process and may be in selection process. The conclusion of the research is that there is no correlation among counseling techniques, empathy behaviour in counseling and ethics behaviour in counseling with client satisfaction.
\end{abstract}

Keywords: Interpersonal communication, counseling techniques, empathy behaviour, ethical behaviour, client satisfaction

\section{Pendahuluan}

Pedidikan Diploma III Kebidanan merupakan pendidikan vokasional yang menghasilkan Bidan Pelaksana dengan gelar Ahli Madya Kebidanan yang diharapkan dapat membantu memecahkan masalah kesehatan di masyarakat. ${ }^{1}$ Berbekal pengetahuan, keterampilan dan kemampuan yang dikuasainya, lulusan bidan harus mampu menghadapi segenap tantangan dan memenuhi kebutuhan masyarakat dalam pelayanan kebidanan. Tenaga kesehatan yang terampil menjadi salah satu syarat agar masalah kesehatan ibu dan anak dapat ditangani secara optimal.

Terampilnya bidan bisa dicapai dengan melakukan praktik kebidanan yang memberikan kesempatan kepada untuk terjun langsung dalam proses pemberian asuhan kebidanan terhadap klien, sebagai sarana aplikasi teori yang telah mereka peroleh selama perkuliahan di kelas.

Praktik kebidanan meliputi penampilan secara menyeluruh, termasuk dalam komunikasi interpersonal dan konseling, baik personal maupun kelompok. Kegiatan konseling merupakan proses pemberian bantuan yang dilakukan melalui wawancara oleh konselor kepada individu yang sedang mengalami suatu masalah yang bermuara pada teratasinya masalah yang dihadapi oleh klien. Tatacara pelaksanaan konseling dikenal dengan akronim GATHER (Greet, Ask, Tell, Help, Explain, Return). ${ }^{2}$

KIP (komunikasi interpersonal) dan $\mathrm{K}$ (konseling) dilaksanakan tidak hanya memperhatikan aspek teknik konseling, tetapi juga tentang aspek perilaku empati dalam konseling dan aspek perilaku etika dalam konseling. Dalam proses konseling antara 
bidan dengan klien perlu ditumbuhkan sikap empati. Kondisi empati dapat terwujud bila bidan memberikan perhatian kepada klien dan dapat mengetahui apa yang sedang dialami klien. ${ }^{3} \quad$ Penelitian yang dilakukan oleh Widayati (2014) menunjukkan bahwa sebesar $15,4 \%$ bidan belum memahami klien dan memperhatikan kebutuhan klien. ${ }^{4}$ Selama proses konseling berlangsung seorang konselor harus memperhatikan aspek etika yaitu memperhatikan hak-hak klien yang harus dilindungi oleh seorang konselor. ${ }^{3}$ Seorang konselor yang baik akan melakukan konseling dengan menggunakan bahasa yang mudah dipahami, tidak menginterupsidan memotong pembicaraan klien serta menghargai pendapat klien sehingga klien akan merasa puas dan menggunakan alat kontrasepsi. Sebagaimana hasil penelitian yang dilakukan oleh Handayani (2011) menunjukkan bahwa belum terpenuhinya hak mendapatkan informasi. ${ }^{5}$ Keterampilan yang baik dalam memberikan konseling bertujuan meningkatkan pemahaman klien sehingga meningkatkan pula kepuasan karena klien merasa didengarkan dan diperhatikan. ${ }^{4,7}$

Keterampilan merupakan kemampuan seseorang untuk melakukan suatu aktivitas atau pekerjaan. Keterampilan lebih sukar dimiliki daripada pengetahuan. Namun, seseorang yang memiliki keterampilan dengan sendirinya sudah memiliki pengetahuan atas pekerjaan yang mereka lakukan. Pada umumnya keterampilan tidak mudah diperoleh dari perkuliahan, terutama perkuliahan yang tidak disertai studi kasus dan role play. ${ }^{6}$

STIKes Muhammadiyah Ciamis merupakan salah satu Perguruan Tinggi Swasta di Kabupaten Ciamis, yang mempunyai lima program studi salah satunya adalah Program Studi D-III Kebidanan. Program Studi D-III Kebidanan mempunyai jumlah mahasiswa sebanyak 389 terdiri dari tingkat I sebanyak 96 orang, tingkat II sebanyak 134 orang dan tingkat III sebanyak 159 orang.

Dalam proses belajar mengajar, dosen sebagai pengajar akan menggunakan pedoman dalam kurikulum dalam menjalankan tugasnya. Melalui proses belajar mengajar terjadi penyampaian informasi dan ilmu pengetahuan serta penanaman nilai-nilai maupun sikap. ${ }^{8}$ Pada semester II mahasiswa mendapatkan pembelajaran Mata Kuliah Komunikasi dalam Praktik Kebidanan. Selain pembelajaran teori, mahasiswa juga melakukan praktik di laboratorium dengan bimbingan dosen pengampu. Evaluasi pembelajaran dilakukan melalui penilaian dari ujian tulis, ujian praktek dan penugasan.

Hasil laporan CI (Clinical Instructure) pada praktik klinik sebelumnya menyatakan bahwa komunikasi interpersonal kurang baik pada saat praktik di lapangan termasuk pada saat melakukan konseling terutama teknik konseling yang kurang baik, mahasiswa kurang empati dan kurang memperhatikan etika dalam konseling sehingga klien merasa kurang puas dengan pelayanan konseling yang diberikan. Hal ini didukung oleh beberapa hasil penelitian seperti yang dilakukan oleh Rimawati (2011) di Semarang dengan metode kualitatif dari wawancara dengan 5 orang klien menunjukkan bahwa kontak mata yang dilakukan konselor berlebihan sehingga menimbulkan rasa tidak nyaman dan konselor tidak menyampaikan kesimpulan pada saat konseling. ${ }^{9}$ Hasil penelitian yang dilakukan oleh Handayani (2011) di Kota Malang dan Kota Sampit dengan metode kualitatif dari wawancara dengan 8 orang akseptor $\mathrm{KB}$ (isteri), 2 orang PLKB (petugas lapangan keluarga berencana) dan FGD (Focus Group Discussion) dengan para suami menunjukkan bahwa masih banyak klien memperoleh pelayanan konseling KB (keluarga berencana) yang kurang berkualitas yaitu klien mengeluhkan kurangnya penjelasan dari petugas kesehatan, kurang melakukan konseling dan pemberian informasi. ${ }^{5}$ Meskipun mahasiswa harus sudah lulus dengan baik pada mata kuliah komunikasi dalam praktik kebidanan sebelum melakukan praktik, dalam monitoring pelaksanaan praktik kebidanan, selama ini belum pernah dilakukan penilaian terhadap keterampilan KIP danK.

Pengukuran kepuasan klien terhadap kualitas pelayanan khususnya konseling KB harus dilakukan secara berkala. Hal ini sesuai dengan Permenpan Nomor 16 Tahun 2014 bahwa survei kepuasan masyarakat terhadap pelayanan publik dilakukan minimal 1 tahun sekali, ${ }^{10}$ STIKes Muhammadiyah Ciamis pun belum pernah melakukan penelitian tentang 
kepuasan klien, khususnya yang terkait dengan pelayanan konseling $\mathrm{KB}$ oleh mahasiswa ketika praktik di lapangan. Penulis menduga jika nilai keterampilan KIP danK baik, maka tingkat kepuasan klien akan baik pula. Berdasarkan hasil penelitian yang dilakukan oleh Rimawati (2006) dengan metode crossectional bahwa terdapat hubungan antara konseling dengan kepuasan akseptor KB. ${ }^{9}$

Penilaian kepuasan terdiri dari keberadaan pelayanan, ketanggapan pelayanan dan profesionalisme. ${ }^{11-13}$ Dalam penelitian ini hanya dapat dilakukan dua aspek penilaian yaitu ketanggapan pelayanan dan profesionalisme. Keberadaan pelayanan tidak dilakukan penilaian karena mahasiswa tidak secara penuh berada di tempat pelayanan tetapi dibagi secara bergantian untuk praktik di lapangan.

\section{Metode}

Penelitian ini menggunakan rancangan observasional analitik dengan pendekatan potong lintang. ${ }^{14-16}$ Variabel bebas adalah keterampilan KIP danK (teknik konseling, perilaku empati dalam konseling, perilaku etika dalam konseling), variabel terikat adalah kepuasan klien dan variabel perancunya adalah nilai mata kuliah komunikasi dalam praktik kebidanan.

Subjek pada penelitian ini adalah mahasiswa tingkat III Program Studi D III Kebidanan STIKes Muhammadiyah Ciamis sebanyak 46 orang dan calon akseptor $\mathrm{KB}$ yang datang ke BPM (bidan praktik mandiri) dinilai apakah memenuhi kriteria inklusi dan ekslusi selanjutnya calon akseptor KB dipilih secara konsekutif sampai tercapai 46 orang. Penelitian ini dilakukan selama 1 bulan yaitu pada bulan Agustus 2015. Instrumen yang digunakan yaitu daftar tilik keterampilan Komunikasi Interpersonal dan Konseling serta kuesioner kepuasan atas pelayanan konseling KB.

Data hasil penelitian dianalisis dengan uji korelasi untuk menganalisis hubungan keterampilan komunikasi interpersonal dan konseling dengan kepuasan klien.

\section{Hasil}

Subjek penelitian terdiri dari 46 mahasiswa dan 46 klien. Berikut ini digambarkan karakteristik klien yang merupakan akseptor baru.

\section{Tabel 1. Karakteristik Klien}

\begin{tabular}{lccc}
\hline \multicolumn{1}{c}{ Karakteristik } & n & \% & Nilai p \\
\hline Umur & & & \\
$<20$ tahun & 1 & 2 & 0,295 \\
20-35 tahun & 36 & 78 & \\
$>35$ tahun & 9 & 20 & \\
Pekerjaan & & & \\
Bekerja & 4 & 9 & 1,000 \\
Tidak bekerja & 42 & 91 & \\
Pendidikan Terakhir & & & \\
SD & 7 & 15 & 0,134 \\
SMP & 14 & 30 & \\
SMA & 20 & 43 & \\
PT & 5 & 12 & \\
Jumlah Anak & & & \\
$\leq 2$ orang & 36 & 78 & 0,722 \\
$>$ 2 orang & 10 & 22 & \\
\hline
\end{tabular}

Tabel 1 menunjukkan umur terbanyak klien yaitu 20-35 tahun, ibu dengan tidak bekerja, ibu dengan pendidikan SMA dan ibu mempunyai anak $\leq 2$ orang.

\section{Tabel 2. Pemilihan Alat Kontrasepsi}

\begin{tabular}{lcc}
\hline $\begin{array}{c}\text { Pemilihan alat } \\
\text { kontrasepsi }\end{array}$ & n & \% \\
\hline Pil & 10 & 21 \\
Suntik 1 bulan & 4 & 9 \\
Suntik 3 bulan & 26 & 56 \\
AKDR & 3 & 7 \\
Implant & 3 & 7 \\
\hline
\end{tabular}

Dari tabel 2, terlihat bahwa semua klien menggunakan alat kontrasepsi, frekuensi tertinggi yaitu klien menggunakan alat kontrasepsi suntik 3 bulan yaitu sebanyak $56 \%$. 
Tabel 3. Hubungan antara Teknik Konseling, Perilaku Etika dalam Konseling, Perilaku Empati dalam Konseling, Nilai Komunikasi dalam Praktik Kebidanan dengan Kepuasan Klien

\begin{tabular}{|c|c|c|c|c|c|c|c|}
\hline \multirow{3}{*}{$\begin{array}{c}\text { Keterampilan Konseling } \\
\text { KB }\end{array}$} & \multicolumn{4}{|c|}{ Kepuasan Klien } & \multirow{2}{*}{\multicolumn{2}{|c|}{ Jumlah }} & \multirow[t]{3}{*}{ Nilai $\mathrm{p}^{*}$} \\
\hline & \multicolumn{2}{|c|}{ Tidak Puas } & \multicolumn{2}{|c|}{ Puas } & & & \\
\hline & $\mathrm{n}$ & $\%$ & $\mathrm{n}$ & $\%$ & $\mathrm{~N}$ & $\%$ & \\
\hline \multicolumn{8}{|l|}{ Teknik Konseling } \\
\hline Tidak Baik & 2 & 100 & 0 & 0 & 2 & 100 & 0,489 \\
\hline Baik & 21 & 48 & 23 & 52 & 44 & 100 & \\
\hline \multicolumn{8}{|l|}{$\begin{array}{l}\text { Perilaku Empati dalam } \\
\text { konseling }\end{array}$} \\
\hline Tidak Baik & 1 & 50 & 1 & 50 & 2 & 100 & 1,000 \\
\hline Baik & 22 & 50 & 22 & 50 & 44 & 100 & \\
\hline \multicolumn{8}{|l|}{ Perilaku Etika dalam } \\
\hline \multicolumn{8}{|l|}{ Konseling } \\
\hline Tidak Baik & 2 & 50 & 2 & 50 & 4 & 100 & 1,000 \\
\hline Baik & 21 & 50 & 21 & 50 & 42 & 100 & \\
\hline \multicolumn{8}{|l|}{ Nilai Komunikasi } \\
\hline$\leq 65$ & 0 & 0 & 1 & 100 & 1 & 100 & 0,181 \\
\hline $66-70$ & 4 & 36,4 & 7 & 63,6 & 11 & 100 & \\
\hline $71-75$ & 13 & 65 & 7 & 35 & 20 & 100 & \\
\hline$\geq 76$ & 6 & 43 & 8 & 57 & 14 & 100 & \\
\hline
\end{tabular}

Keterangan : *) uji Kai kuadrat

Hasil analisis uji statistik Kai kuadrat menunjukkan bahwa tidak terdapat hubungan yang bermakna antara teknik konseling, perilaku empati dalam konseling, perilaku etika dalam konseling dengan kepuasan klien, dengan nilai $\mathrm{p}>0,05$. Selanjutnya dilakukan analisis korelasi Rank Spearman.

Tabel 4. Korelasi antara Teknik Konseling, Perilaku Empati dan Perilaku Etika dalam Konseling dengan Kepuasan Klien

\begin{tabular}{lcc}
\hline Korelasi Antara & Koefisien Korelasi $\left(\mathbf{r}_{\mathbf{s}}\right)$ & Nilai p \\
\hline Teknik Konseling dengan kepuasan klien & 0,271 & 0,069 \\
Perilaku empati dengan kepuasan klien & 0,158 & 0,295 \\
Perilaku etika dengan kepuasan klien & $-0,032$ & 0,832 \\
Nilai komunikasi dengan kepuasan klien & 0,002 & 0,990 \\
\hline
\end{tabular}

Keterangan : $r_{s}=$ koefisien korelasi Rank Spearman.

Hasil analisis uji korelasi menunjukkan hubungan antara teknik konseling, perilaku empati dan perilaku etika dalam konseling dengan kepuasan klien tidak bermakna dengan nilai $\mathrm{p}>0,05$.

\section{Pembahasan}

Secara keseluruhan klien dalam penelitian ini menggunakan alat kontrasepsi, diduga karena pada saat persamaan persepsi dengan penguji, peneliti menjelaskan akan mengganti kompensasi jasa dan alat kontrasepsi yang digunakan sehingga menjadi bias seleksi pada sampel klien, kemungkinan penguji menyebarluaskan untuk pelayanan alat kontrasepsi gratis, yang seharusnya ada penekanan terhadap bidan yang akan menjadi penguji bahwa responden atau klien jangan diberitahu untuk pelayanan alat kontrasepsi gratis karena klien tersebut akan dijadikan sampel dalam penelitian. Dalam kuesioner terdapat butir penilaian keberhasilan konseling yaitu pengambilan keputusan namun tidak tampak perbedaaan sehingga terjadi bias.

Kondisi ini juga diduga kemungkinan sudah ada niat dari diri klien sendiri dan motivasi yang tinggi didukung dengan biaya gratis, sehingga semua klien menggunakan alat kontrasepsi yang terdistribusi pada pemakaian alat kontrasepsi pil, suntik 1 bulan, suntik 3 bulan, AKDR (alat kontrasepsi dalam rahim) dan implan. Hal ini sejalan dengan penelitian yang dilakukan oleh Putriningrum 
dengan hasil menunjukkan bahwa sebanyak $70,58 \%$ atas kesadaran dan kemauan sendiri untuk memilih KB suntik, bukan dari motivasi bidan yang hanya sebesar $29,42 \%$. Pemilihan alat kontrasepsi oleh klien merupakan hak untuk dapat merencanakan dengan baik tentang pengaturan kelahiran mereka. ${ }^{17}$ Informasi KB dari sumber lain juga bisa didapat sehingga sehingga mempunyai motivasi yang kuat, seperti hasil penelitian Indriyanti yang menunjukkan bahwa responden mendapatkan informasi tentang $\mathrm{KB}$ dari televisi yaitu sebesar $87,5 \% .{ }^{18}$

Pada penelitian ini terdapat 44 orang $(95,7 \%)$ melakukan teknik konseling baik namun masih ada 21 orang merasa tidak puas dengan pelayanan konseling $\mathrm{KB}$ Ketidakpuasan yang terjadi tampak dari hasil analisis klien yang merasa kurang puas atas ketanggapan petugas konseling terhadap kebutuhan, informasi yang diberikan, pertanyaan pemahaman terhadap informasi yang diberikan, petunjuk tempat rujukan dan kunjungan ulang.

Secara uji statistik dengan uji korelasi menunjukkan tidak terdapat hubungan antara teknik konseling dengan kepuasan klien (nilai $p>0,05$ ). Hal ini diduga karena pada saat proses konseling KB berlangsung, mahasiswa hanya dinilai melakukan tidaknya langkahlangkah dari teknik konseling, namun tidak memperhatikan kualitas langkah konseling KB tersebut. Klien mengharapkan pelayanan yang berkualitas, seperti hasil penelitian Najib yang menyatakan bahwa kualitas konseling ditentukan oleh kemampuan memberi informasi yang lengkap, terbuka, tidak ada informasi yang disembunyikan dan memberikan gambaran yang jelas tentang kontrasepsi sehingga calon akseptor KB mempunyai pengetahuan yang memadai dan kesadaran yang tinggi untuk ber-KB. Kualitas hubungan yang harus diciptakan pada saat konseling bersifat interpersonal dalam suasana keramahan, saling perhatian, dan saling memberi kesempatan saling bertanya. Klien harus secara jelas memperoleh informasi bagaimana harus menjamin keberlangsungan partisipasinya dalam program sesuai dengan mekanisme yang ada dalam sistem pelayanan. Petugas pelayanan perlu mempunyai pengetahuan dan keterampilan teknis yang memadai dalam pelayanan kontrasepsi, komunikasi dan konseling sehingga pelayanan KB dapat diberikan sesuai standar. ${ }^{19}$

Tidak terdapatnya hubungan antara teknik konseling dengan kepuasan klien sejalan dengan hasil penelitian Purwanti, Suherni dan Astuti bahwa tidak terdapat hubungan antara mutu layanan konseling AKDR dengan tingkat kepuasan akseptor, tidak terdapatnya hubungan diduga karena konseling tidak dapat dilakukan sesuai standar sepenuhnya dan tidak memenuhi seluruh komponen pemberian informasi. $^{20}$ Juga hasil penelitian Amirah bahwa tidak terdapat hubungan antara interaksi menjelaskan dokter pada pasien saat konsultasi dengan kepuasan pasien. ${ }^{21}$

Berdasarkan hasil penelitian menunjukkan bahwa perilaku empati dalam konseling baik sebanyak 44 orang $(95,7 \%)$ namun terdapat 22 orang diantaranya merasa tidak puas dengan pelayanan konseling KB. Ketidakpuasan yang terjadi diantaranya masih ada beberapa klien yang menyatakan kurang puas terhadap pemberian pujian atau dukungan terhadap pernyataan klien dan kurang puas terhadap nada bicara dan volume suara dari pemberi pelayanan konseling KB. Dalam kuesioner tentang perilaku empati masih perlu adanya perbaikan. Dalam penelitian ini empati yang dinilai didapat dari langkah-langkah konseling dan yang melakukan penilaian adalah bidan, tidak dibuat kuesioner khusus yang diisi langsung oleh klien karena empati itu hanya bisa dirasakan oleh klien. Dalam hal ini kemungkinan bisa terjadi measurement bias.

Hasil uji statistik dengan uji korelasi menunjukkan tidak terdapat hubungan antara perilaku empati dalam konseling dengan kepuasan klien dengan nilai $p>0,05$. Hal ini diduga bahwa pemahaman tentang empati yang masih kurang karena di dalam proses pembelajaran belum terdapat mata kuliah khusus tentang empati tetapi terintegrasi di dalam setiap mata kuliah. Pada saat pembelajaran praktik di laboratorium kemungkinan dosen pengampu belum maksimal dalam melakukan role play pada mata kuliah komunikasi dalam praktik kebidanan, dan pada saat mahasiswa melakukan praktik di laboratorium yang berperan mahasiswa sebagai bidan dan mahasiswa sebagai klien jadi belum merasakan bagaimana kalau melakukannya 
dengan kondisi nyata sehingga kurang berempati. Hal ini sejalan dengan teori Hoffman menyatakan bahwa pada situasi tertentu seseorang dapat berempati lebih baik dibandingkan dengan situasi yang lain. Hal ini disebabkan situasi dan tempat yang berbeda dapat memberikan situasi yang berbeda pula. Suasana yang berbeda inilah yang dapat meninggirendahkan empati seseorang.

Pada penelitian ini yang melakukan konseling adalah mahasiswa sehingga dilihat dari karakteristik usia lebih muda dari klien yang diberikan pelayanan. Hal juga sesuai dengan pernyataan Hoffman bahwa tingkat empati seseorang yang semakin meningkat dengan bertambahnya usia, karena kemampuan pemahaman perspektif juga meningkat bersamaan dengan usia. Ketika usia bertambah, pengalaman hidup pun bertambah. Pengalaman hidup ini pula yang akan menumbuhkan empati individu terhadap orang lain dan lingkungannya.

Tidak terdapat hubungan antara perilaku empati dalam konseling dengan kepuasan klien sejalan dengan hasil penelitian Amirah bahwa tidak terdapat hubungan antara interaksi mendengarkan dokter dengan pasien saat konsultasi dengan kepuasan pasien. ${ }^{21}$ Juga sejalan dengan hasil penelitian Widayanti, Widagdo dan Purnami menunjukkan bahwa sebagian besar keterampilan konseling oleh bidan dalam kategori cukup baik sebanyak $65 \%$, namun juga masih ditemukan bidan yang kurang memahami klien dan memperhatikan kebutuhan klien. ${ }^{4}$

Seorang konselor harus menunjukkan rasa empati, mendengarkan secara aktif, mengajukan pertanyaan dengan jelas, memberikan motivasi dan pujian. Dalam proses konseling antara bidan dan klien perlu ditumbuhkan perilaku perhatian. Kondisi ini dapat terwujud bila bidan bersedia memberikan perhatian kepada klien, mengamati, mendengarkan dan dapat mengetahui apa yang sedang dialami klien berkaitan dengan pilihan alat kontrasepsi. Dengan perilaku perhatian bidan yang baik mampu mengidentifikasi masalah klien dan membantu mengatasi masalah tersebut.

Berdasarkan hasil penelitian Eti Rimawati menunjukkan bahwa sikap konselor menerima dan memahami permasalahan klien ditunjukkan dengan sikap anggukan kepala, kontak mata dan ungkapan perasaan perhatiannya kepada klien, konselor memberikan perhatian penuh terhadap permasalahan klien ditunjukkan dengan memberikan perhatiannya dengan memperhatikan dan memberikan tanggapan terhadap keluhan klien, konselor memberikan dukungan terhadap keluhan klien ditunjukkan dengan memberikan dukungan berupa nasehat, semangat dan mengatur diri menjadi lebih baik. ${ }^{9}$ Perilaku empati dalam penelitian ini adalah hal yang berkaitan dengan perhatian terhadap masing-masing individu dengan menunjukkan mendengarkan saat klien menyampaikan permasalahan, memperhatikan dan memahami klien sebelum, selama dan sesudah konseling, melakukan kontak mata, volume suara memadai, intonasi dan ketepatan bicara memadai serta memberikan pujian atau dukungan terhadap klien sehingga klien merasa puas.

Menurut Gamrin, bahwa sikap ramah dan kepedulian yang ditunjukkan seorang petugas sangat penting dalam menghadapi pasien. Mereka cenderung bersedia bersikap terbuka terhadap keluhan yang dihadapinya ketika petugas menunjukkan empati. Pasien juga akan menilai kejujuran dari petugas. Faktor inilah yang menyebabkan kualitas layanan yang dirasakan oleh pelanggan turut menentukan puas atau tidaknya seorang pelanggan terhadap penyedia jasa. Ketika pasien merasakan bahwa petugas bersikap ramah, memiliki kepedulian, kejujuran dan memberikan rasa nyaman selama berhubungan maka pasien akan merasa puas. ${ }^{22}$

Berdasarkan hasil penelitian menunjukkan bahwa perilaku etika dalam konseling baik sebanyak42 orang $(91,3 \%)$ namun terdapat 21 orang diantaranya merasa tidak puas dengan pelayanan konseling KB. Ketidakpuasan yang dirasakan oleh klien disebabkan oleh karena klien masih merasa kurang puas terhadap pernyataan pemberi pelayanan konseling pada saat menghargai pendapat klien dan memotong pembicaraan klien. Secara uji statistik dengan uji korelasi didapatkan nilai p $>0,05$ berarti tidak terdapat hubungan antara perilaku etika dalam konseling dengan kepuasan klien.

Pada dasarnya pada saat konseling berlangsung berada dalam suasana tidak menghakimi, menerima dan peduli, 
perlakukan klien dengan sopan dan menunjukkan rasa hormat untuk setiap klien, menghormati pilihan klien, informasi yang disampaikan dengan menggunakan bahasa yang mudah dipahami. Konseling menerapkan komunikasi yang diawali dengan interaksi saling percaya dengan klien. Nada suara rendah digunakan, kritik dan penilaian dihindari, dengar dan cermati perasaan atau pesan dibalik ucapan, dan hormati kerahasiaan klien. Seperti halnya penelitian yang dilakukan oleh Oktarina menyatakan bahwa sebanyak $67,5 \%$ kerahasiaannya terjaga. ${ }^{23}$ Juga penelitian yang dilakukan oleh Larasati bahwa hak kerahasiaan akseptor KB Suntik dengan kategori baik sebanyak 55,6\%. Bidanbidan tersebut selalu berusaha menyimpan rahasia pada orang lain tentang alat $\mathrm{KB}$ yang sering dipakai oleh klien-kliennya. ${ }^{24}$

\section{Daftar Pustaka}

1. Kemenkes RI. Kurikulum Inti Pendidikan D-III Kebidanan. Jakarta. BPPSDM Kesehatan Pusat Pendidikan dan Pelatihan Tenaga Kesehatan; 2011

2. Saraswati I, Tarigan, LH. Modul Pelatihan Keterampilan Komunikasi Interpersonal dan Konseling. Jakarta: Maternal Neonatal Health; 2002. 22-4, 36, 177-9

3. Dalami E, Dahlia I, Rochima. Komunikasi dan Konseling dalam Praktik Kebidanan. Jakarta: Trans Info Medika; 2009. 68-70

4. Widayanti RS, WidagdoL, Purnami CT. Analisis Pelaksanaan Konseling Kontrasepsi oleh Bidan di Wilayah Dinas Kesehatan Kota Surakarta. GASTER. 2 Februari2014; 11 (2): 78-81

5. Handayan L, Suharmiati, Hariastuti I, Latifah C. Peningkatan Informasi tentang KB: Hak Kesehatan Reproduksi yang Perlu Diperhatikan oleh Program Pelayanan Keluarga Berencana. Bulletin Penelitian Sistem Kesehatan. 3 Juli 2012; 5(3): 292

6. Parulin Hutapea NT, editor. Kompetensi Plus. Jakarta: Gramedia Pustaka Utama; 2008

7. BKKBN. Panduan Konseling KB untuk Dokter Praktek Swasta. Jakarta; 2003

8. Sardiman AM. Interaksi dan Motivasi Belajar Mengajar. Jakarta: Fajar Interpratam; 2003

9. Rimawati, E. Indriani. Indreswari, S.A Keterampilan Konselor Klinik VCT (studikasus di BPKM Paru Semarang). Semantik; 2011. 84-6
10. Peraturan Menteri Pendayagunaan Aparatur Negara dan Reformasi Birokrasi Nomor 16 Tahun 2014 tentang Pedoman Survei Kepuasan Masyarakat terhadap Penyelenggaraan Pelayanan Publik

11. Supranto J. Pengukuran Tingkat Kepuasaan Pelanggan untuk Menaikkan Pangsa Pasar. Jakarta: Rineka Cipta; 2011

12. Supranto J. 10 Prinsip Kepuasan Pelanggan. Jakarta: PT Elex Media Komputindo; 2002. 76-7, 85-6, 233

13. Tjiptono F. Manajemen Jasa. Yogyakarta: ANDI; 2005

14. Dahlan SM. Besar Sampel Dan Cara Pengambilan Sampel. Jakarta: Salemba Medika; 2012. 108-12, 130-1

15. Satroasmoro S, Ismael S. Dasar-dasar Metodologi Penelitian Klinis. Jakarta: Sagung Seto; 2011. 4-5

16. Dahlan SM. Statistik Untuk Kedokteran dan Kesehatan: Deskriftip, Bivariat dan Multivariat, Cetakan Kedua. Jakarta: Salemba Medika; 2012

17. Putriningrum R. Faktor-faktor yang Mempengaruhi Ibu dalam Pemilihan Kontrasepsi KB Suntik di BPS Ruvina urakarta.Jurnal Kesmadaska; 2012: 3-9 http:dandanjurnal.stikeskusumahusada.ac.iddaninde x.phpdanJKdanarticledanviewdan24dan87

18. Indriyanti IS. Sumber Informasi yang Memengaruhi Keputusan Menjadi Akseptor KB Wanita (Studi Kasus di Kelurahan Bandarharjo Semarang). 2011 http:dandaneprints.undip.ac.iddan33311dan1dan Indah_Silvia.pdf

19. Najib. Pengetahuan Klien dan Kualitas Pelayanan sebagai Dasar Pemilihan Alat Kontrasepsi Hormonal. Jurnal Kesehatan Masyarakat Nasional. 2011; 6(3): 112-4

20. Purwanti IA, Suherni T, Astuti E. Hubungan Mutu Layanan Konseling AKDR dengan Tingkat Kepuasan Akseptor Bidan Delima di Kota Semarang.2010.36-7 http:dandanjurnal.unimus.ac.id

21. Amirah, Sudirman I, Maidin A. Hubungan Komunikasi (Mendengarkan, Menjelaskan dan Kompetensi) dengan Kepercayaan, Kepuasan dan Loyalitas Pasien Instalasi Rawat Jalan Rumah Sakit di Makasar. 2013

22. Gamrin B. Faktor-faktor yang Memengaruhi Mutu Pelayanan Kesehatan di Rumah Sakit: Tinjauan dati Persepsi Pasien. Fakultas Kesehatan Masyarakat Unuversitas Hasanudin Makasar. 2007

23. Oktarina, Sugiarto M. Persepsi Akseptor KB terhadap Kualitas Pelayanan KB di Puskesmas Provinsi Jawa Timur dan Jawa Tengah. Buletin Penelitian Sistem Kesehatan.2009;16(2)

24. Larasati EW, Mufdilah. Pemenuhan Hak-Hak Akseptor KB Suntik Bulanan di BKIA 'Aisyiyah Karang Kajen Yogyakarta. 2010 http:dandanopac.say.ac.iddaniddaneprintdan 1639 